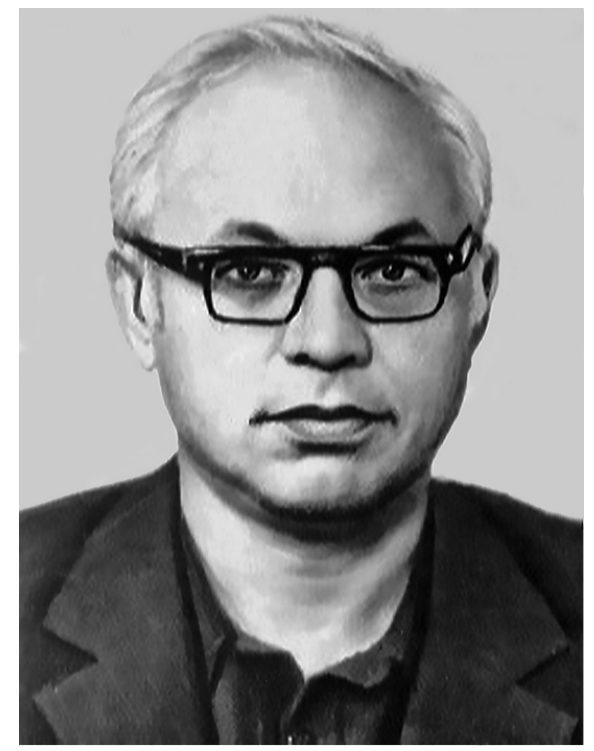

\title{
АНАТОЛІЙ ВОЛОДИМИРОВИЧ СКОРОХОД (короткий біографічний нарис)
}

А. В. Скороход народився 10 вересня 1930 року в м. Нікополь Дніпропетровської області в сім'ї вчителів. Батьки вчителювали в робітничих та сільських селищах навколо Нікополя. Батько, Володимир Олексійович, викладав математику, фізику, астрономію в старших класах середньої школи. Мати, Надія Андріївна, була вчителькою російської та української мов, історії, музики та співу, а також математики. Вона мала талант актриси, писала оповідання, вірші.

Дитинство Анатолія Володимировича припало на тяжкі роки - руїна після громадянської війни, згодом - колективізація на селі i, як наслідок, голод. Анатолій почав навчатися в школі у віці 7 років, проте змушений був перервати навчання на час, коли Україна була окупована німецькими військами під час Другої світової війни.

Повоєнні роки (1946 - 1947 рр.) в Україні знову були голодними, і сім'я Скороходів (батьки та двоє синів - Анатолій і молодший за нього на 4 роки Валерій) у 1946 році, рятуючись від голоду, переїхала в м. Ковель на Волині, де Володимир Олексійович отримав посаду директора

Скорочена версія статті, опублікованої в журналі „European Mathematical Society” (2014 р.), в перекладі українською М. І. Портенка. 
середньої школи. В тій же школі продовжив своє навчання і Анатолій. Він був успішним учнем з усіх шкільних предметів. Хоча у нього завжди була зацікавленість математикою, проте тоді він не відчував, що це - його майбутнє покликання. В 1948 році після закінчення школи із золотою медаллю Анатолій, за порадою батька, вступив до Київського університету ім. Тараса Шевченка на механіко-математичний факультет. Його наукова робота розпочалася в студентські роки. Під керівництвом Б. В. Гнєденка та Й. І. Гіхмана він почав займатися теорією ймовірностей.

В часи, коли Анатолій Володимирович закінчував навчання в університеті (це був 1953 р.), Б. В. Гнєденко запропонував йому подумати над тим, як узагальнити принцип інваріантності Донскера на випадок, коли граничним процесом для сум незалежних випадкових величин $\epsilon$ не вінерів процес, як це було у Донскера, а загальний процес із незалежними приростами. Ця проблема і стала головною темою розмірковувань Анатолія Володимировича під час навчання в аспірантурі при Московському університеті протягом 1953 - 1956 рр. Вступав він до аспірантури при Київському університеті, і його керівником мав бути Б. В. Гнєденко. Однак так сталося, що Борис Володимирович повинен був відбути в довгострокове закордонне відрядження, і тому його учні були відправлені на навчання до Москви. Керівником аспіранта А. В. Скорохода було призначено професора Московського університету С. Б. Динкіна.

Цей період у житті Анатолія Володимировича був визначним у багатьох аспектах. В середині 50-х років на механіко-математичному факультеті навколо видатних вчителів зібралася представницька община молодих талановитих математиків з усіх куточків Радянського Союзу. Ці молоді люди вбачали своє майбутнє в служінні фундаментальній науці. Серед них Анатолій Володимирович вирізнявся своєю незалежністю в дослідницькій роботі, а також сміливістю і відвагою мислення та оригінальністю своїх підходів до вирішення проблем. Як він пізніше зізнавався, головним серед того, що він набув під час навчання в аспірантурі, був його досвід участі в роботі семінару, яким керував Є. Б. Динкін. Семінар мав назву „Аналіз, алгебра та теорія ймовірностей”.

Закінчилось навчання Анатолія Володимировича в аспірантурі тріумфальним успіхом. Розмірковуючи над проблемою узагальнення принципу інваріантності Донскера на загальні процеси 3 незалежними приростами, він сформулював і довів низку найзагальніших граничних теорем для випадкових процесів, ввівши кілька нових топологій у простір функцій без розривів 2-го роду та запропонувавши новий оригінальний метод доведення граничних теорем - так званий метод одного ймовірнісного простору. Важливість ідей зовсім юного тоді математика була підтверджена всією подальшою історією розвитку теорії випадкових процесів. Терміни „топологія Скорохода”, „метрика Скорохода”, „простір Скорохода” входять 3 тих пір в усі фундаментальні монографії з цієї теорії.

Кандидатську дисертацію, присвячену граничним теоремам для випадкових процесів, Анатолій Володимирович захистив у травні 1957 року. Ї̈̈ науковий рівень значно перевищував середній рівень таких дисертацій, і серед спеціалістів поширеною була думка, що це рівень докторської дисертації і що А. В. Скороход заслуговував уже тоді присудження йому докторського ступеня. Однак з певних причин так не сталося.

В 1957 - 1964 pp. Анатолій Володимирович викладав у своїй ,alma mater” - Київському університеті. В 1961 році у видавництві цього університету вийшла з друку його перша книга під 
назвою „Исследования по теории случайных процессов”, яка фактично була його докторською дисертацією. Захистив він ії в 1963 році. Звання професора йому було присвоєно в 1964 році.

На початку 1964 року в Інституті математики Академії наук України було створено відділ теорії випадкових процесів. Анатолій Володимирович перейшов працювати на посаду завідувача цього відділу, не полишаючи викладання в Київському університеті. В 1967 році його було обрано членом-кореспондентом Академії наук України, а в 1985 році - іiі дійсним членом.

Одразу ж після повернення з Москви, на початку 1957 року, розпочались регулярні бесіди між А. В. Скороходом та Й. І. Гіхманом, які започаткували не лише дружні стосунки між ними, а й довгострокову плідну співпрацю: разом вони написали багато відомих книг, присвячених різним аспектам теорії випадкових процесів.

В Інституті математики Анатолій Володимирович пропрацював майже 30 років: з 1964 по 1993 рік. Це були роки напруженої і плідної роботи. Теорія стохастичних диференціальних рівнянь, якою він почав займатися не без впливу Й. І. Гіхмана, стала однією з найулюбленіших тем його досліджень. Вже в його першій книзі „Исследования по теории случайных процессов” викладено нові на той час підходи до теорії стохастичних диференціальних рівнянь, отримано нові результати, з'явилась нова проблематика. Далі були книги з цієї теорії, написані спільно 3 Й. І. Гіхманом (1968 і 1982 рр.). Але не тільки теорія стохастичних диференціальних рівнянь привертала увагу Анатолія Володимировича. Він довів у цей час низку теорем про локальну структуру процесів Маркова, як неперервних, так і тих, що не мають розривів 2-го роду, ввів поняття сильних і слабких лінійних випадкових операторів, поняття розширеного стохастичного інтеграла, поняття стохастичної напівгрупи. Крім того, він отримав нові результати в теорії міри в нескінченновимірних просторах, теорії стійкості систем, що описуються стохастичними диференціальними рівняннями. Саме в ці роки Анатолій Володимирович став одним із світових лідерів теорії випадкових процесів.

А. В. Скороход відіграв видатну роль у розвитку Київської ймовірнісної школи. Широкий спектр його наукових зацікавлень і активна праця в різноманітних напрямках досліджень, його педагогічний хист були надзвичайними. Цілі покоління студентів зростали під впливом його лекцій, його підручників і монографій, написаних або ним самим, або у співавторстві 3 колегами. Київські семінари з теорії ймовірностей (республіканський - при Київському університеті - під керівництвом Анатолія Володимировича та семінар при Інституті математики, керований ним спільно з Ю. Л. Далецьким) стали надзвичайно авторитетними в період 3 кінця 60-х і до початку 90-х років. Дослідники не лише з Радянського Союзу, а й з його зарубіжжя прагнули зробити наукові доповіді за результатами своїх досліджень на засіданнях цих семінарів, щоб почути відгук про свою роботу від Анатолія Володимировича. Він керував роботою аспірантів, що прибували до Києва 3 різних куточків Радянського Союзу, а також з Китаю, В'єтнаму, Угорщини, Східної Німеччини, Нікарагуа тощо. Під його керівництвом захищено 56 кандидатських та 17 докторських дисертацій.

31993 року і до кінця свого життя А. В. Скороход був професором Департаменту статистики та теорії ймовірностей Мічиганського університету (США), викладаючи курси підвищеного рівня з теорії випадкових процесів. Не полишав там і наукової роботи, зокрема, досліджував поведінку динамічних систем під впливом випадкових факторів, виступав із доповідями на 
засіданнях різних семінарів (Детройт, Міннеаполіс тощо). В 2000 році його було обрано членом Американської академії мистецтв і науки.

А. В. Скороход жив математикою. Ось деякі його висловлювання про царицю наук. „Тільки допитлива до самозабуття людина може бути хорошим математиком. . . 3 допомогою математики часто відкриваються нові несподівані факти. В мистецтві прекрасні твори завжди містять щось несподіване, хоч і не все несподіване $є$ прекрасним. У математиці ж несподіване завжди прекрасне.... Немає нічого прекраснішого, ніж просте зрозуміле доведення нетривіального твердження". В одному з листів він писав, що думає про математику завжди. Бриніння проблеми, яку він на той час обдумував, було в його голові неперервним і безупинним. Він не шукав у літературі якихось методів, що допомогли б йому вирішити свою проблему, він створював свій власний підхід, власні методи і конструкції, і ці його творіння визначали напрямки подальших досліджень, i не лише його самого. Прикладом може служити так звана проблема відбиття (the Skorokhod reflecting problem) або ж проблема вкладення (the Skorokhod embedding problem).

Одного разу Анатолія Володимировича запитали, як він ставиться до соціальної активності науковця. Його відповіддю було: „Негативно. Вважаю, що науковець має бути професіоналом”. Проте за певних обставин він міг продемонструвати власну громадянську мужність. Так, у квітні 1968 року він був у складі групи із 139 науковців, письменників, митців, робітників і студентів, які написали листа до керівництва Радянського Союзу з протестом проти відновлення практики закритих судів над людьми, що наважились критикувати владу за порушення прав громадян. В ті часи далеко не кожен міг відважитись взяти участь у такій акції, оскільки це загрожувало переслідуваннями з боку всесильної тоді влади. Для А. В. Скорохода - людини з розвиненими почуттями власної гідності та внутрішньої свободи - це був цілком природний крок - приєднатись до людей, що протестували проти беззаконня. Інший подібний крок Анатолій Володимирович наприкінці 80-х років був серед групи людей, які започаткували в Україні „Рух” - широку організацію громадян, що наважились виступити проти гегемонії Комуністичної партії в житті держави. Власне, це вже були останні роки існування Радянського Союзу - в грудні 1991 року він перестав існувати. Як тільки вже в незалежній Україні Рух перетворився на політичну партію, Анатолій Володимирович вийшов із цієї організації.

Одним із найбільших захоплень Анатолія Володимировича, крім математики, була поезія. Його улюбленими поетами були І. Бунін, Б. Пастернак, О. Мандельштам, А. Ахматова, Л. Костенко, Й. Бродський. Він знав напам'ять значну частину їхніх творів і у колі друзів чи під час прогулянок міг протягом кількох годин діставати зі своєї пам'яті й озвучувати рядки цих чарівників поетичного слова. Принагідно і завжди до речі цитував рядки 3 поезій Тараса Шевченка та Лесі Українки, до яких ставився з великим пієтетом.

Коли він пішов із життя, до кошика 3 квітами, принесеними на церемонію прощання, була прикріплена записка з написом „А bright star has returned to the Universe”. Ці ж слова в перекладі українською „Сяюча зірка повернулась у Всесвіт” написані на гранітній плиті над прахом А. В. Скорохода, що покоїться на Байковому цвинтарі в Києві.

I. I. Кадирова 